\title{
Improving HN Fuse Link Process \& Product Quality using Six Sigma Methodology
}

\author{
Dr. Rajendra Takale and Swapnil Dere
}

\begin{abstract}
This paper deals with manufacturing of five different types of fuses namely $H N-000, H N-0, H N-1, H N-2$, $H N-3$. Company had found that rejection of fuses of all types was more than 7\%. This research paper is based on implementing Six Sigma methodologies at one of the suppliers of company to improve the process of manufacturing HN Fuse link. This paper also discusses the additional benefits achieved post implementation of Six sigma methodology like minimizing lead time, defects, rejections to name a few. Overall improvement in quality and raised the sigma level from 4.31 to 4.56.
\end{abstract}

Keywords--- Six Sigma, DMAIC Method, RPN, Pareto Charts, Poka Yoke

\section{INTRODUCTION}

\subsection{Six Sigma}

Cix sigma is -"A comprehensive \& flexible system for achieving, sustaining \& maximizing business success is six sigma."[5] Six sigma deals with strategies of continuous improvement \& defect reduction to achieve a quality standard of not more than 3.4 defects per million opportunities (DPMO).In today's business environment, the six sigma standard is synonymous with excellence.

Six sigma is uniquely driven by a close understanding of customer needs, disciplined use of facts, data, and statistical analysis \& diligent attention to managing, improving, \& reinventing business processes [3] [4]. Dr. Genichi Taguchi, a quality management expert, defines quality of a product as "the loss incurred by the society when a substandard product is sent to the market." This loss is due to the deviation in the functional characteristics of the product/ process from the target value. The deviation of the performance from the target is due to some controllable \& non-controllable factors. Hence, to achieve good \& consistent quality not only the target response but also the variation should be taken into consideration.

Six sigma is a holistic approach to business improvement that includes philosophy, performance measurement, improvement frameworks \& a tool kit, all of which is intended to complement \& enhance existing engineering, service and manufacturing processes \& can serve as both, an enterprise governance model $\&$ a tactical improvement engine. It is a disciplined, data-driven approach \& a methodology for

Dr. Rajendra Takale, Associate Professor, MBA, Sinhgad Institute of Management, Pune, India, E-mail: rrtakale@gmail.com

Swapnil Dere, Pune, India, E-mail: swapnildere3000@gmail.com eliminating defects in any process \& thus is a product of that process.

\subsection{Evolution of Six Sigma}

Six sigma was started at Motorola in 1987 by Mr. Bill Smith to improve the quality of their products. However, this concept gained popularity only after GE implemented it under the guidance of Mr. Jack Welch in 1995 [6]. Philosophy of Six sigma includes constant focus on customer, Data driven management, focus on business process, proactive management, think team, continuous improvement, Rigor based approach. Six sigma is excellent at what it does-driving bottom-line improvements in short period of time [2].

\subsection{Six Sigma Methodologies}

Six sigma can be implemented through two methodologies namely;

1. DMAIC (Define, Measure, Analysis, Improve, Control)

2. DMADV (Define, Measure, Analysis, Verify, Control)

Project deals with existing product so that DMAIC methodology is useful for this implementation.

Table 1: Phases in Six Sigma Methodology

\begin{tabular}{|c|c|c|}
\hline Phase & Step & Tools \\
\hline \multirow[t]{3}{*}{$\begin{array}{l}\text { Define } \\
\text { phase }\end{array}$} & Project charter & $\begin{array}{c}\text { Problem statement, Goal statement, } \\
\text { Current sigma, Target sigma, cost } \\
\text { saving }\end{array}$ \\
\hline & High level & SIPOC \\
\hline & $\begin{array}{c}\text { Specify } \\
\text { responsibilities } \\
\& \text { authority for } \\
\text { the project }\end{array}$ & $\begin{array}{l}\text { Roles of the team members- } \\
\text { Who will give inputs } \\
\text { Who will give review } \\
\text { Who will be accountable } \\
\text { Who will sign off }\end{array}$ \\
\hline \multirow[t]{4}{*}{$\begin{array}{c}\text { Measure } \\
\text { phase }\end{array}$} & $\begin{array}{c}\text { Define defect, } \\
\text { opportunities, } \\
\text { unit }\end{array}$ & $\begin{array}{l}\text { Based on CTQ's, process } \\
\text { knowledge\& benchmarking }\end{array}$ \\
\hline & $\begin{array}{l}\text { Develop data } \\
\text { collection plan }\end{array}$ & Sampling plan \\
\hline & $\begin{array}{c}\text { Collect the } \\
\text { data \& tabulate }\end{array}$ & Dataset \& check-sheet \\
\hline & $\begin{array}{c}\text { Calculate } \\
\text { sigma baseline }\end{array}$ & DPMO, Sigma level calculation \\
\hline \multirow[t]{2}{*}{$\begin{array}{l}\text { Analysis } \\
\text { phase }\end{array}$} & $\begin{array}{c}\text { Determine root } \\
\text { causes }\end{array}$ & Cause \& Effect Diagram, Pareto \\
\hline & $\begin{array}{l}\text { Prepare Action } \\
\text { Plan to explore } \\
\text { various }\end{array}$ & Brainstorming \& SWOT analysis \\
\hline $\begin{array}{c}\text { Improve } \\
\text { phase }\end{array}$ & $\begin{array}{l}\text { Assess Failure } \\
\text { Modes of }\end{array}$ & FMEA \\
\hline
\end{tabular}




\begin{tabular}{|c|c|c|}
\hline \multirow{1}{*}{} & $\begin{array}{c}\text { Reduce risks } \\
\text { associated with } \\
\text { natantina }\end{array}$ & $\begin{array}{c}\text { Plan \& } \\
\text { Execute }\end{array}$ \\
\cline { 2 - 3 } & $\begin{array}{c}\text { Fine-tune the } \\
\text { potential }\end{array}$ & Verification \\
\cline { 2 - 3 } & $\begin{array}{c}\text { Check } \\
\text { performance }\end{array}$ & Drainstorming \\
\hline $\begin{array}{c}\text { Control } \\
\text { phase }\end{array}$ & $\begin{array}{c}\text { Develop \& } \\
\text { Implement the }\end{array}$ & $\begin{array}{c}\text { Developing \& } \\
\text { implementing } \\
\text { the Control }\end{array}$ \\
\hline
\end{tabular}

\section{STUDY OF PROCESS}

Table 2: Study of Suppliers \& Process

\begin{tabular}{|c|c|c|c|c|}
\hline Supplier & Input & Process & Output & Customer \\
\hline 1.Siddhi & Man-Workers & \multirow{9}{*}{$\begin{array}{c}\text { HN } \\
\text { Fuse } \\
\text { Assemb } \\
\text { ly }\end{array}$} & \multirow{9}{*}{$\begin{array}{c}\text { HN } \\
\text { Fuse } \\
- \text { HN } \\
000 \\
-H N 0 \\
-H N 1 \\
-H N 2 \\
-H N 3\end{array}$} & \multirow{9}{*}{$\begin{array}{l}\text { External } \\
\text { Customer }\end{array}$} \\
\hline Industries & Material- & & & \\
\hline 2.Amod & Fuse Body, End & & & \\
\hline Industries & Plate, & & & \\
\hline 3.Jyoti & Inner plate, Fuse & & & \\
\hline Ceramic & Element, Gasket, & & & \\
\hline \multirow{3}{*}{$\begin{array}{l}\text { 4. Shriniws } \\
\text { Metals }\end{array}$} & Indicator Wire, & & & \\
\hline & Sand & & & \\
\hline & $\begin{array}{c}\text { Machine- } \\
\text { Spot welding, } \\
\text { Solder Gun, mV } \\
\text { Tester }\end{array}$ & & & \\
\hline
\end{tabular}

\section{NEED FOR THE STUDY}

In today's business scenario improve process, use of automation, improve quality, reduce lead time are main keys to grow business. This helps to increase productivity \& ultimately profit will increase. Fuse production of company is 40,000 per month. So this shows there market importance \& customers demand for fuse. For the month of March \& April, it was found that rejection of fuse was more than $6 \%$ at assembly line which affect their production schedule \& profit. This rejection was affecting the company's marketing strategy $\&$ it was difficult to fulfill the requirement of customers with desired quality \& on time. So, company has started this project to reduce defects, improve process \& reduce lead time. This project will also help to save the cost.

\section{PROBLEM STATEMENT}

1. Rejection of fuse was up to $7 \%$ during assembly.

2. Quality was affected for which company is known to whole market.

3. Productivity was reduced which affects the profit of company.

\section{OBJECTIVES OF STUdY}

The objectives behind carrying out the project are as follows,

1. To improve Rolled Throughput Yield (RTY) of HN fuses link.

2. To improve sigma level of the process.

3. To reduce defects occurring during process
4. To achieve Cost saving by reducing rejections

5. To improve Quality of HN fuse

Figure 1: Assembly Procedure Chart (Suggested)

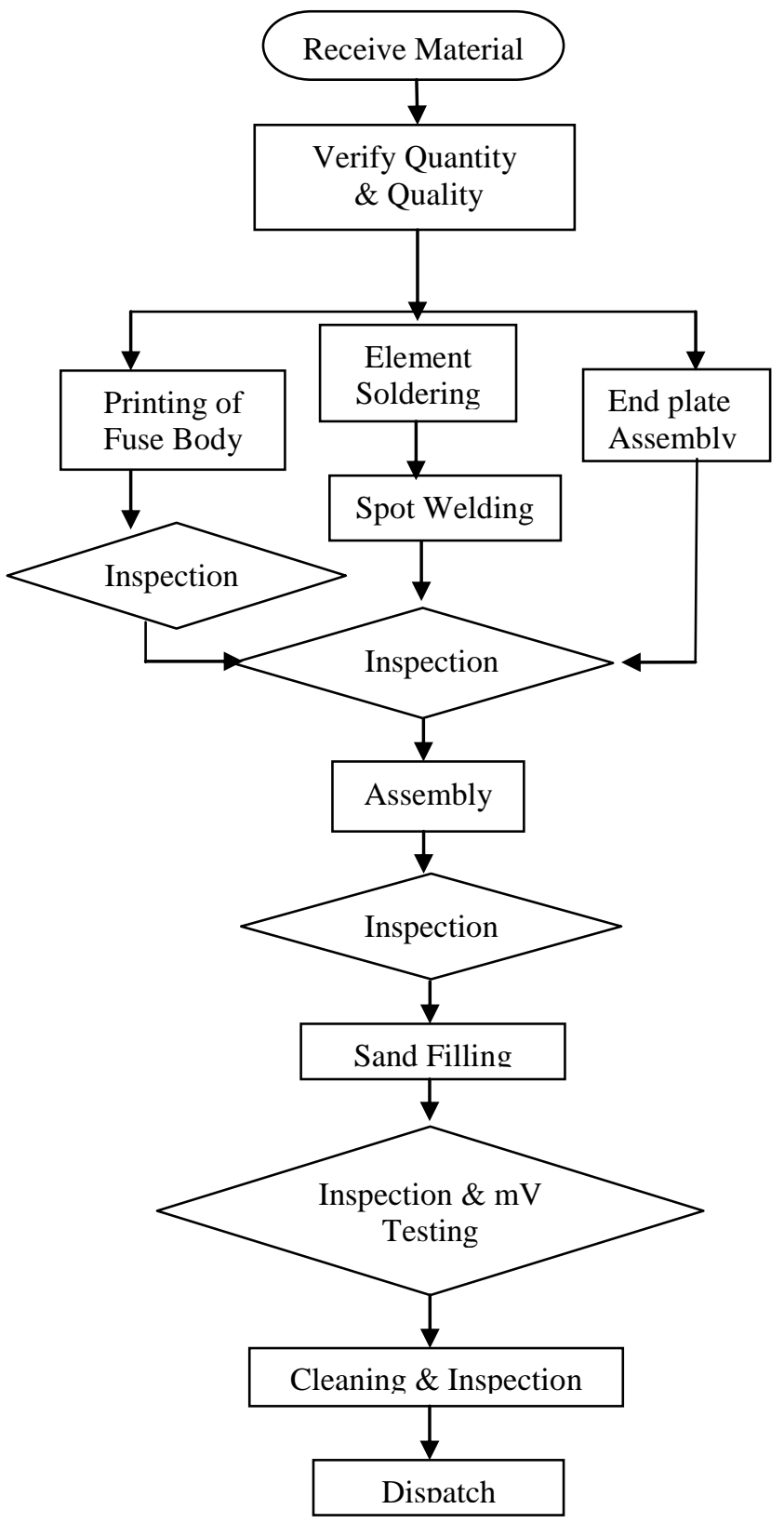

VI. RESEARCH METHODOLOGY

This paper is based on primary data which is collected during actual working on the job \& observations made. It includes collecting daily rejections, dimension measurements before \& after improvements, take down voltage readings for different fuses.

The secondary data is only used for understanding six sigma methodologies which consists of magazines, research papers, case studies. SOP's, machine \& fixture manual, rejection sheet for previous months were referred \& studied during project as secondary data.

\subsection{Sampling Methodology}

1. Random Sampling:- Sample size $=10$ products 
Population $=100$ Purpose - Inspection $\&$ check mV readings

2. Systematic Sampling:- Sample size $=1$ i.e. every 30th unit of welding machine \& Population $=75$ pieces per machine per hour

Purpose -

3. Check strength of element after applying $5 \mathrm{~kg}$ weight.

4. Check continuity \& repeatability of welding machine.

\subsection{Data Collection}

Output data is divided into Discrete Data \& Continuous Data. Discrete data is countable. Eg. No of defects, no of errors; whereas continuous data is measurable. Eg. Voltage, Temperature etc

Rejection data is collected \& tabulated in table no. 3

Table 3: Rejection Data Collection from May to July

\begin{tabular}{|c|c|c|c|c|c|}
\hline $\begin{array}{l}\text { Sr. } \\
\text { No }\end{array}$ & Process & Type of Defect & May & June & July \\
\hline 1 & \multirow{3}{*}{$\begin{array}{c}\text { Fuse body } \\
\text { visual } \\
\text { defects }\end{array}$} & $\begin{array}{l}\text { Fuse body chip } \\
\text { off }\end{array}$ & 156 & 171 & 52 \\
\hline 2 & & $\begin{array}{l}\text { Poor quality } \\
\text { printing }\end{array}$ & 0 & 10 & 0 \\
\hline 3 & & Printing damaged & 0 & 15 & 0 \\
\hline 4 & \multirow{3}{*}{$\begin{array}{l}\text { Plug } \\
\text { piercing }\end{array}$} & Damaged plug & 57 & 71 & 0 \\
\hline 5 & & $\begin{array}{l}\text { Plug not flushed } \\
\text { end while piercing }\end{array}$ & 0 & 0 & 0 \\
\hline 6 & & $\begin{array}{l}\text { Damaged end } \\
\text { plate }\end{array}$ & 43 & 58 & 0 \\
\hline 7 & \multirow{4}{*}{$\begin{array}{l}\text { Indicator } \\
\text { clip } \\
\text { assembly }\end{array}$} & Damaged gasket & 0 & 0 & 0 \\
\hline 8 & & $\begin{array}{l}\text { Indicator red paint } \\
\text { missing }\end{array}$ & 0 & 0 & 0 \\
\hline 9 & & $\begin{array}{l}\text { Damaged } \\
\text { indicator }\end{array}$ & 0 & 0 & 0 \\
\hline 10 & & $\begin{array}{c}\text { Damaged } \\
\text { indicator clip }\end{array}$ & 0 & 0 & 0 \\
\hline 11 & \multirow{4}{*}{$\begin{array}{c}\text { Solder } \\
\text { deposition }\end{array}$} & Damaged element & 0 & 73 & 0 \\
\hline 12 & & $\begin{array}{c}\text { Element poor } \mathrm{Ag} \\
\text { plating }\end{array}$ & 0 & 28 & 0 \\
\hline 13 & & $\begin{array}{c}\text { Solder material on } \\
\text { neck }\end{array}$ & 491 & 258 & 132 \\
\hline 14 & & $\begin{array}{l}\text { Inadequate } \\
\text { soldering }\end{array}$ & 477 & 234 & 97 \\
\hline 15 & \multirow{3}{*}{ Spot welding } & $\begin{array}{l}\text { Inner plate poor } \\
\text { Ag plating }\end{array}$ & 0 & 0 & 0 \\
\hline 16 & & $\begin{array}{c}\text { Inner plate } \\
\text { damaged }\end{array}$ & 0 & 12 & 0 \\
\hline 17 & & Missed spot & 0 & 0 & 0 \\
\hline 18 & \multirow{3}{*}{$\begin{array}{l}\text { Fuse link } \\
\text { assembly }\end{array}$} & $\begin{array}{l}\text { Damaged end } \\
\text { plate }\end{array}$ & 44 & 59 & 0 \\
\hline 19 & & $\begin{array}{c}\text { Indicator wire } \\
\text { broken }\end{array}$ & 295 & 129 & 45 \\
\hline 20 & & $\begin{array}{c}\text { Screw thread in } \\
\text { fuse body slipped } \\
\text { off }\end{array}$ & 0 & 0 & 0 \\
\hline 21 & \multirow{2}{*}{ Sand filling } & Printing rubbed & 0 & 0 & 0 \\
\hline 22 & & Plug damaged & 65 & 71 & 0 \\
\hline 23 & $\begin{array}{c}\text { Weight } \\
\text { measurement }\end{array}$ & Under weight & 0 & 0 & 0 \\
\hline
\end{tabular}

\begin{tabular}{|c|c|c|c|c|c|}
\hline 24 & \multirow{2}{*}{$\begin{array}{c}\text { Visual } \\
\text { inspection }\end{array}$} & $\begin{array}{c}\text { Scratch marks on } \\
\text { fuse body }\end{array}$ & 0 & 0 & 0 \\
\cline { 3 - 5 } & $\begin{array}{c}\text { Plating \& printing } \\
\text { rejection }\end{array}$ & 0 & 0 & 0 \\
\hline 26 & & Other rejections & 411 & 150 & 174 \\
\hline 27 & $\begin{array}{c}\text { mV drop } \\
\text { testing }\end{array}$ & Not within band & 613 & 287 & 299 \\
\hline & & Total & 2652 & 1626 & 799 \\
\hline
\end{tabular}

Major reductions in rejections are highlighted in the above table. Using this rejection data, RTY \& Sigma level is calculated.

Table 4: RTY \& Sigma Level Calculations from April to July

\begin{tabular}{|c|c|c|c|c|}
\hline & APRIL & MAY & JUNE & JULY \\
\hline Total Rejection & 2944 & 2652 & 1626 & 799 \\
\hline Quantity supplied & 39172 & 43875 & 31481 & 25775 \\
\hline $\begin{array}{c}\text { Total Quantity } \\
\text { Produced }\end{array}$ & 42116 & 46527 & 33107 & 26574 \\
\hline $\begin{array}{c}\text { Percentage of } \\
\text { Rejection }\end{array}$ & 7 & 5.7 & 4.91 & 3.01 \\
\hline RTY & 93 & 94.3 & 95.09 & 96.99 \\
\hline Sigma Level & 4.3 & 4.36 & 4.41 & 4.56 \\
\hline
\end{tabular}

Rejection details for each type of HN fuse (HNO00 to HN3) are collected to study the improvements in reducing rejections \& improving sigma level.

Table 5: Rejection Details of Each Fuse Type

\begin{tabular}{|c|c|c|c|}
\hline \multirow{2}{*}{ Fuse Type } & \multicolumn{3}{|c|}{ May } \\
\cline { 2 - 4 } & TP & TR & \%R \\
\hline HN 000 & 14915 & 689 & 4.62 \\
\hline HN 0 & 7802 & 378 & 4.84 \\
\hline HN 1 & 11218 & 631 & 5.62 \\
\hline HN 2 & 8974 & 594 & 6.62 \\
\hline HN 3 & 3618 & 360 & 9.95 \\
\hline Total & 46527 & 2652 & 5.70 \\
\hline
\end{tabular}

\begin{tabular}{|c|c|c|c|}
\hline \multirow{2}{*}{ Fuse Type } & \multicolumn{3}{|c|}{ June } \\
\cline { 2 - 4 } & TP & TR & $\%$ R \\
\hline HN 000 & 7094 & 257 & 3.62 \\
\hline HN 0 & 7306 & 306 & 4.18 \\
\hline HN 1 & 11007 & 540 & 4.90 \\
\hline HN 2 & 5151 & 283 & 5.49 \\
\hline HN 3 & 2549 & 240 & 9.42 \\
\hline Total & 33107 & 1626 & 4.91 \\
\hline
\end{tabular}

\begin{tabular}{|c|c|c|c|}
\hline \multirow{2}{*}{ Fuse Type } & \multicolumn{3}{|c|}{ July } \\
\cline { 2 - 4 } & TP & TR & $\%$ R \\
\hline HN 000 & 4544 & 137 & 3.01 \\
\hline HN 0 & 2472 & 86 & 3.48 \\
\hline HN 1 & 11753 & 382 & 3.25 \\
\hline HN 2 & 5504 & 137 & 2.49 \\
\hline HN 3 & 2301 & 57 & 2.48 \\
\hline Total & 26574 & 799 & 3.01 \\
\hline
\end{tabular}

*where, TP $=$ Total Production, TR $=$ Total Rejections \& $\% \mathrm{R}=$ Percentage Rejections

\subsection{Data Analysis \& Interpretation}

Data analysis can be done with the help of following three tools namely;

1. Cause \& Effect Diagram 
2. Failure Mode \& Effect Analysis (FMEA)

3. Pareto Analysis

\subsubsection{FMEA}

Six sigma works on basis of calculated risk i.e. Assessment of risk \& Reduction of risk.

This paper is related to process FMEA used to uncover problems related to an existing process.

FMEA quantifies risk in terms of three categories namely Severity, Occurrence \& Detection 12 [1]. Each category is rated on a scale from 1 to 10 , with lower rating representing a lower risk. After the severity, occurrence \& detection ratings are developed, the scores are multiplied together to provide a Risk Priority Number [7]. RPN represents the risk associated with each failure mode [8]. Ref: Table: 6 FMEA Chart

FMEA chart analysis:

1. Major risk is associated with 4 types of defects namely solder material on neck, inadequate soldering, broken indicator wire \& Not within band defect.

2. Not within band defect is having highest RPN with 126 value

3. Recommended actions are decided \& implemented to reduce RPN value.

4. Responsibilities are allocated to respective person to initiate these activities.

\subsubsection{Pareto Analysis}

The basic principle of PARETO is "Around $80 \%$ of overall effect is contributed by $20 \%$ of causes \& vice versa." This analysis helps to find out few important factors \& trivial many.

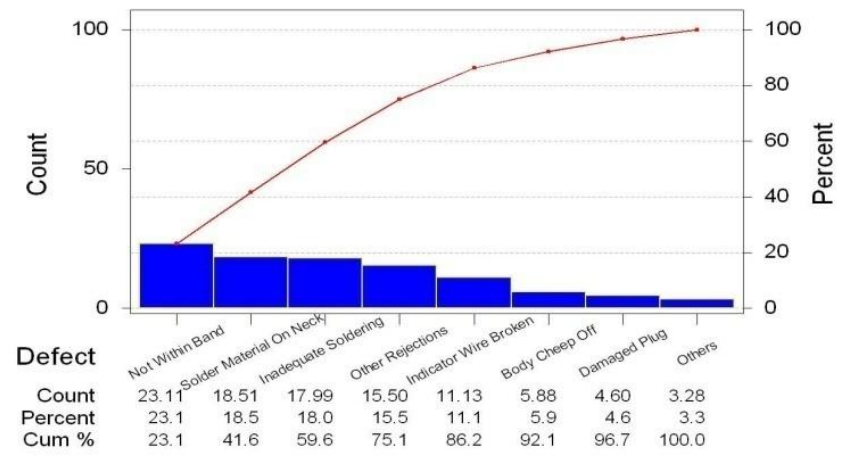

Figure 2: PARETO Diagram for May

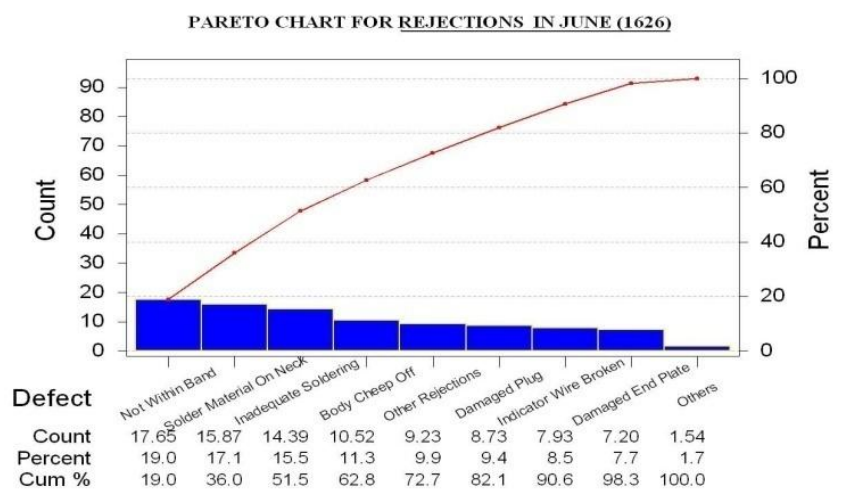

Figure 3: PARETO Diagram for June

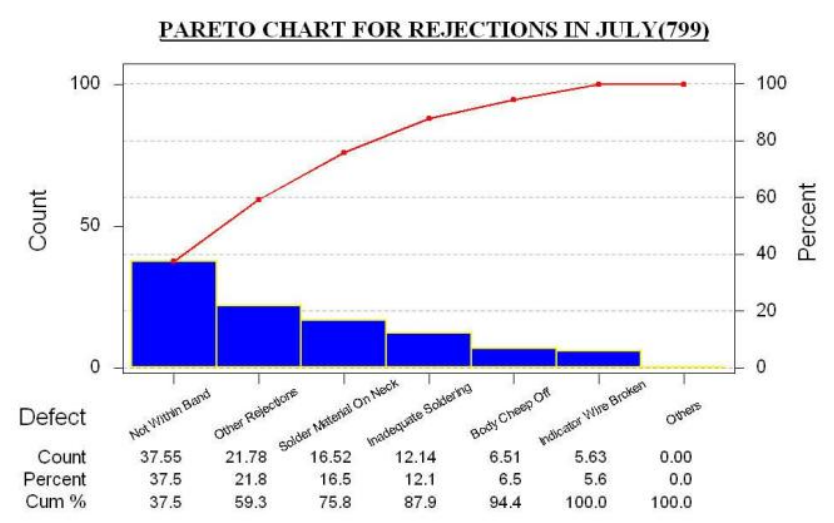

Figure 4: PARETO Diagram for July

\subsubsection{Analysis from Pareto Diagrams}

Table 7: 80-20\% analysis of Pareto diagrams

\begin{tabular}{|c|c|c|c|c|}
\hline \multirow{2}{*}{ Factors } & \multicolumn{3}{|c|}{ Month } & \multirow{2}{*}{ Result } \\
\hline & May & June & July & \\
\hline $\begin{array}{c}\text { Few } \\
\text { Important } \\
\text { Factors }\end{array}$ & $\begin{array}{l}\text { Not within } \\
\text { band, } \\
\text { Solder } \\
\text { material on } \\
\text { neck, } \\
\text { Inadequate } \\
\text { soldering, } \\
\text { Other } \\
\text { rejections, } \\
\text { Indicator } \\
\text { wire } \\
\text { broken }\end{array}$ & $\begin{array}{l}\text { Not within } \\
\text { band, } \\
\text { Solder } \\
\text { material on } \\
\text { neck, } \\
\text { inadequate } \\
\text { soldering, } \\
\text { Body cheep } \\
\text { off, Other } \\
\text { rejections }\end{array}$ & $\begin{array}{c}\text { Not } \\
\text { within } \\
\text { band, } \\
\text { Other } \\
\text { rejection } \\
\text { s, Solder } \\
\text { material } \\
\text { on neck }\end{array}$ & $\begin{array}{c}\text { Important } \\
\text { factors are } \\
\text { reduced }\end{array}$ \\
\hline $\begin{array}{c}\text { Trivial } \\
\text { Many } \\
\text { Factors }\end{array}$ & $\begin{array}{c}\text { Body cheep } \\
\text { off, } \\
\text { Damaged } \\
\text { plug, others }\end{array}$ & $\begin{array}{c}\text { Damaging } \\
\text { plug, } \\
\text { Indicator } \\
\text { wire broke, } \\
\text { Damaged } \\
\text { end plate, } \\
\text { others }\end{array}$ & $\begin{array}{c}\text { Inadequa } \\
\text { te } \\
\text { soldering } \\
\text {, Body } \\
\text { cheep } \\
\text { off, } \\
\text { Indicator } \\
\text { wire } \\
\text { broken, } \\
\text { Others }\end{array}$ & $\begin{array}{c}\text { Trivial } \\
\text { factors are } \\
\text { remained } \\
\text { same }\end{array}$ \\
\hline
\end{tabular}

For statistical analysis from Pareto diagram please refer to Table 8 Annexure 2. 


\section{IMPROVEMENTS}

\section{Making Full Proof Fixtures (Poka Yoke)}

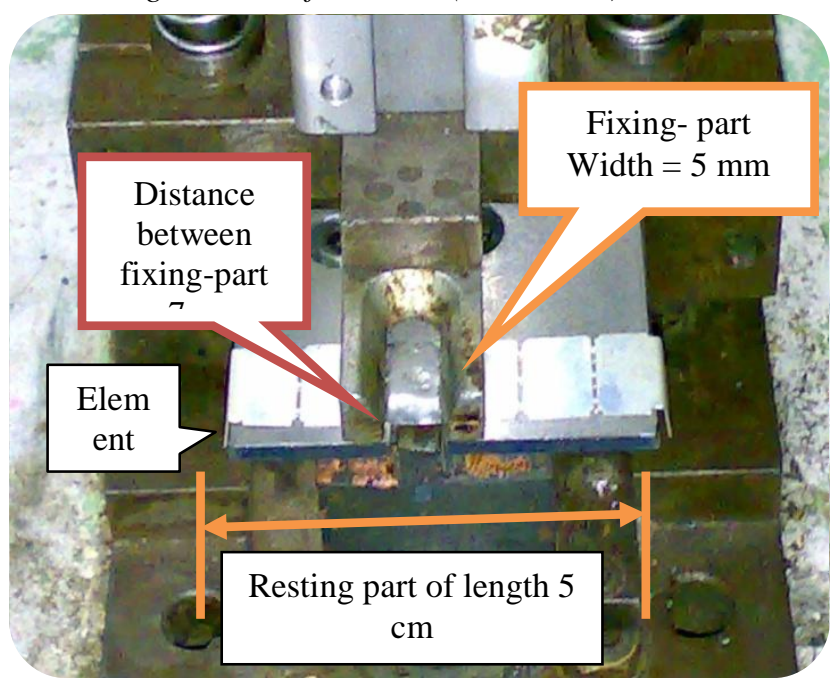

Figure 5: Soldering Fixture

\section{Problem identification:}

1. Solder material gets spread on the element neck even after fixing it in the fixture.

2. Element was getting disturbed during soldering.

3. Length of resting part is not enough to hold element.

4. Distance between two fixing part is more than required.

Technical improvements in the fixture are:

a. Length of resting part is equal to length of element i.e. 5 $\mathrm{cm}$, leading to eliminate the chances of element disturbance during soldering. This is also called as RCO (Reduce Chances of Occurrence).

b. Distance between two fixing parts is reduced from $8 \mathrm{~mm}$ to $7 \mathrm{~mm}$ by increasing the width of fixing part from $4 \mathrm{~mm}$ to $5 \mathrm{~mm}$ which helps to reduce the chances of spreading soldering material on element neck.

\section{Making Changes in Assembly Fixtures}

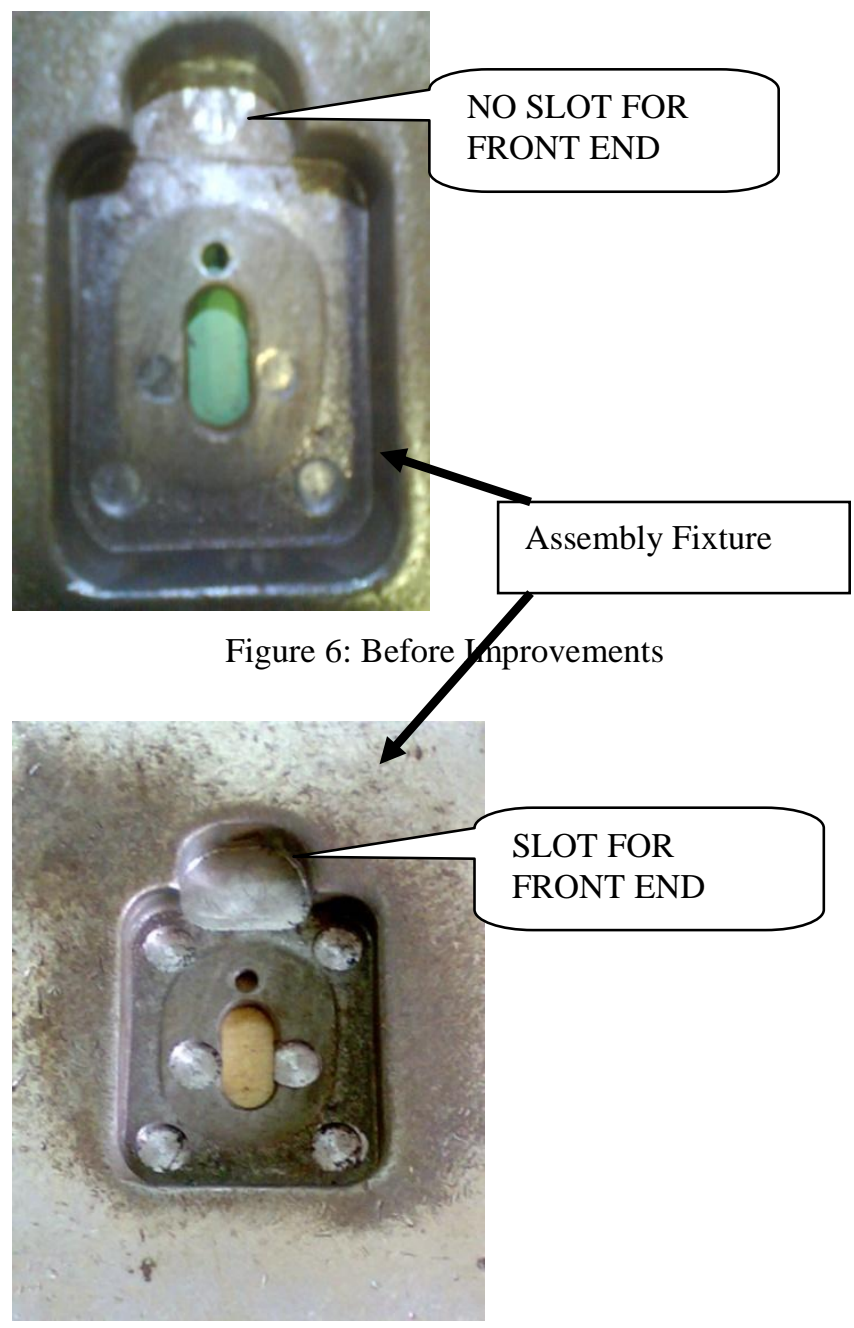

Figure 7: After Improvements

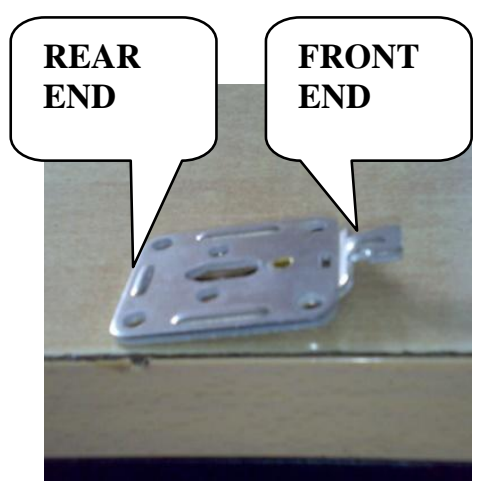

Figure 8: End Plate

Problem Identification:

1. Less tension in the indicator wire causes breakage of wire during screw fitting.

2. Front end was not completely rested on the assembly fixture leading to create less tension in the wire.

A slot is created in assembly fixture for front end of end plate so as to create tension in indicator wire during assembly. 


\section{Kaizen Activity (2S- Seiton)}

"Place for everything \& everything at its place"

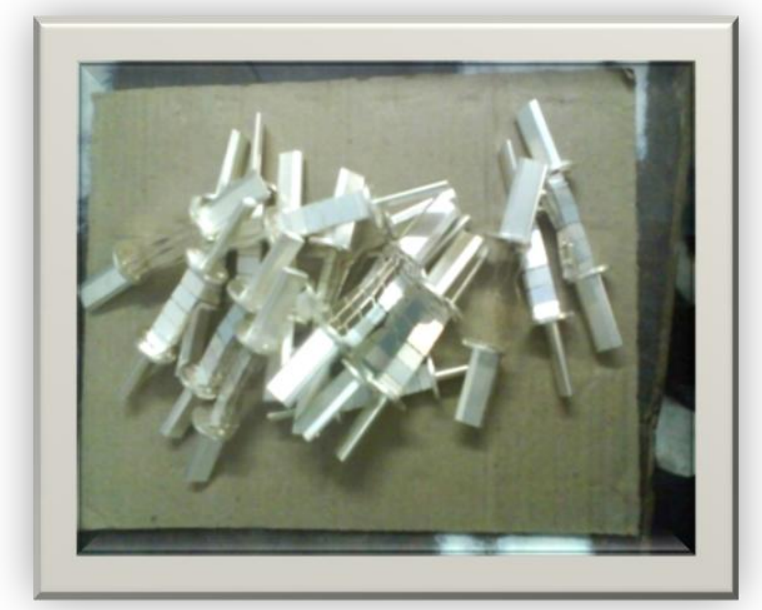

Figure 9: Improper Storage Leads to Damage of Element

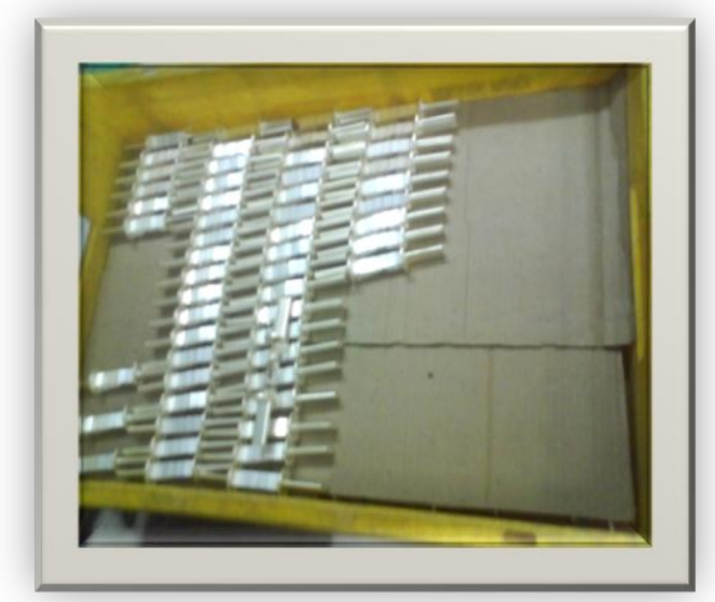

Figure 10: Proper Storage of Elements in Bins

\section{Selection of stopper combination:}

Stoppers are used at welding machines to locate the elements within inner plates. Stoppers are selected randomly by the workers leading to dislocation of the elements. Correct stopper combinations are chosen by trial $\mathrm{n}$ error method such that it helps to weld elements within two inner plates.

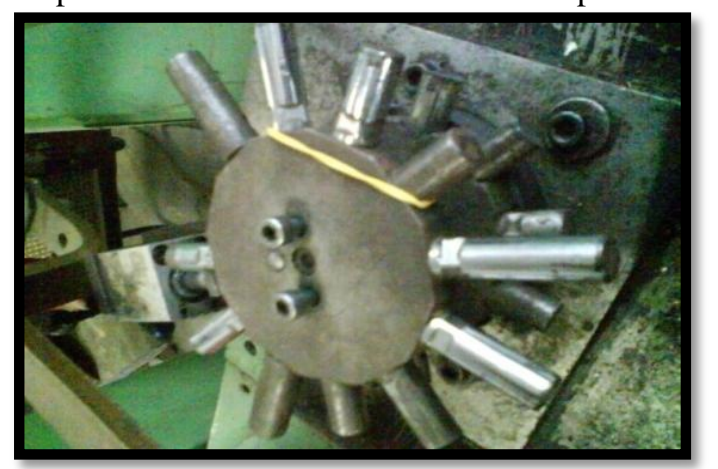

Figure 11: Stopper Combinations are shown Visually for 2 Welding Machines

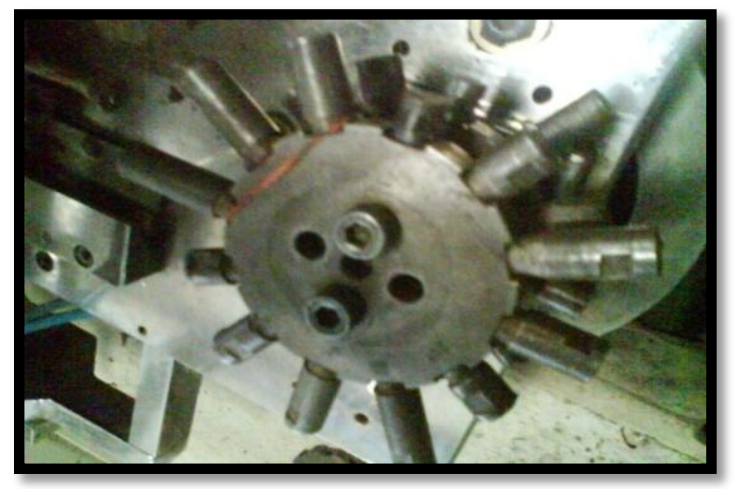

Figure 12: Stopper Combinations are shown visually for 2 Welding Machines

Effect of selecting stopper combination;

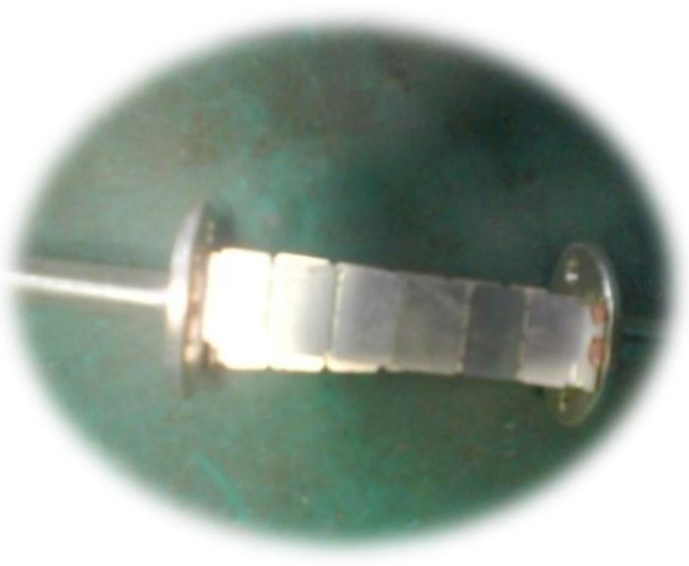

Figure 13: Dislocation of Elements

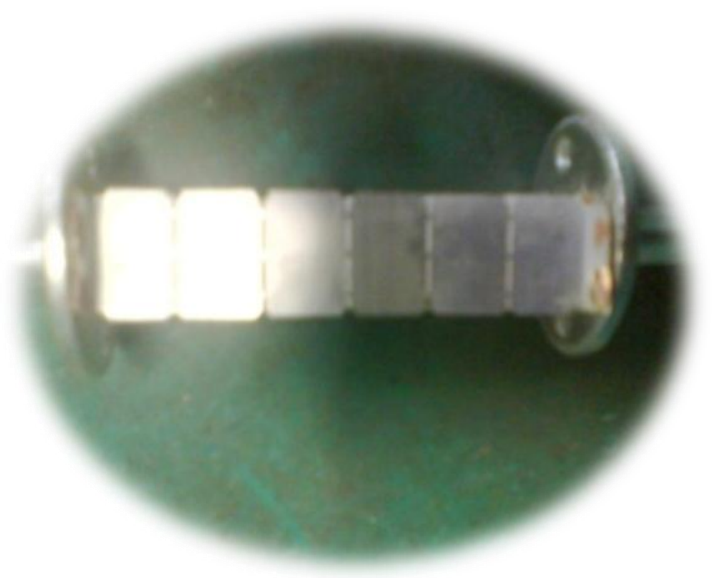

Figure 14: Right allocation of Elements

\section{Purchase of New Temperature Controller}

Temperature controllers are used along with soldering fixtures so as to melt soldering material to spread properly on the plate of element. 
VIII. RESULTS

1. Improved RTY from $93 \%$ to $97 \%$

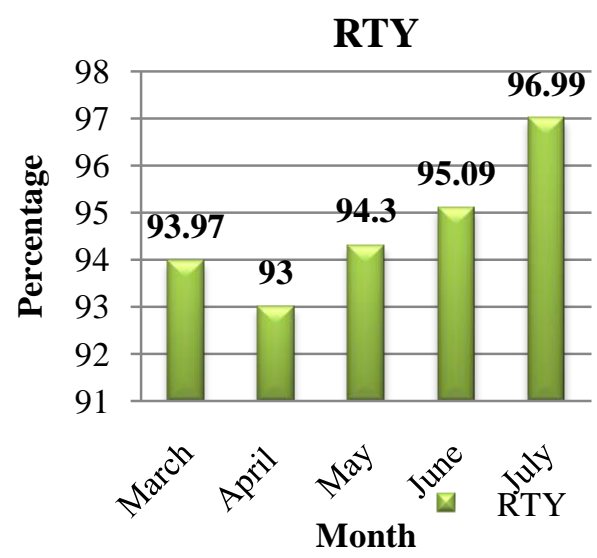

2. Improved Sigma Level from 4.31 to 4.56

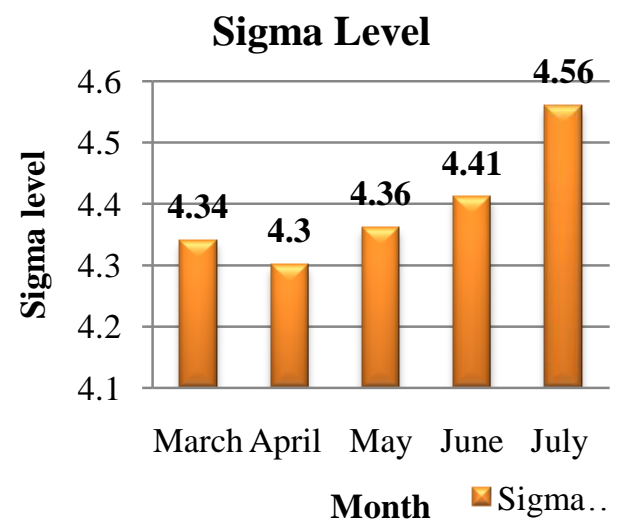

3. Rejections are Reduced from $7 \%$ to $3.01 \%$.

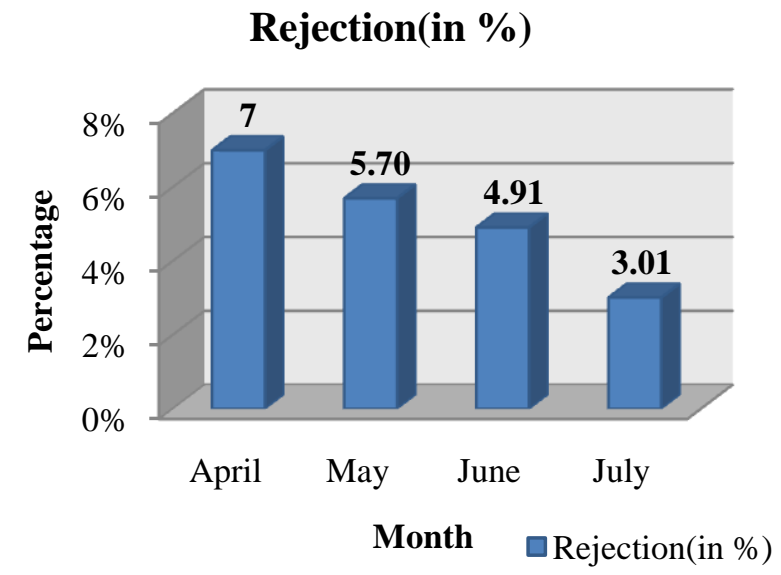

4. Productivity is Improved as DPMO Reduced from 2111 to 1113

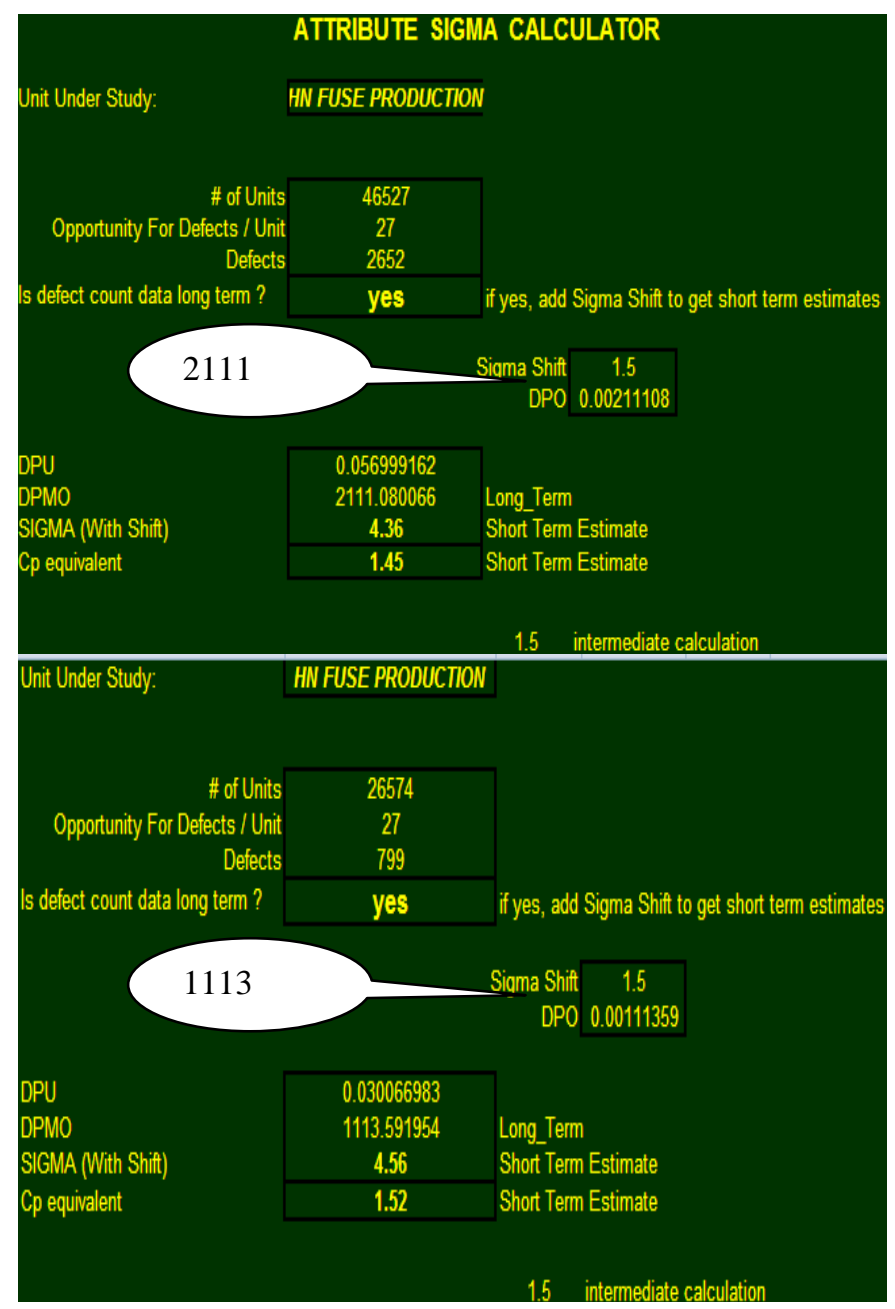

Figure 15: Screen Shot of Sigma Calculator

5. Approx. Cost Saving of 1 Lac Per Annum

It is estimated that approximately the improvement in the process will save Rs. 1, 00,000/- per annum. The saving will increase with more production.

\section{SUGGESTIONS}

1. Continuous use of soldering fixture is must to reduce soldering related defects.

2. Disassembling of rejected fuses should be done within two days after rejection of that particular defect. It leads to reduce inventory \& storage problem.

3. Maintenance should be provided to welding machine \& printing machine which leads to occur improper welding \& printing defect respectively.

4. Continuous use of bins for the storage of material leads to reduce breakage of element.

5. Morale of the workers must be improved to realize them that what the importance of quality is.

6. SOP's (Standard Operating Procedure) for assembly should be followed by the workers. 


\section{CONCLUSIONS}

1. Linking Six sigma program to employees will help in getting better co-operation, improved work culture \& morale.

2. Linking Six sigma to suppliers will help in improving collaboration, which shall result in the effective implementation of six sigma.

3. Six sigma methods help to improve process, quality, and productivity through different phases. It also helps to save the cost leads to improve profit.

4. Workers, operator \& management involvement should be there to improve quality, productivity. Morale plays vital role in improving quality \& productivity.

5. The deviation of the performance from the target is due to some controllable \& non-controllable factors. Hence, to achieve good \& consistent quality not only the target response but also the variation should be taken into consideration.

\section{ABBREVIATIONS}

DMADV - Define Measure Analysis Design Verify

DMAIC - Define Measure Analysis Improve Control

DPMO - Defects per Million Opportunities

FMEA- Failure Mode Effect Analysis

RPN- Risk Priority Number

RTY- Rolled Throughput Yield

SIPOC - Suppliers Inputs Process Output Customers

SOP - Standard Operating Procedure

\section{REFERENCES}

[1] George Michael L; 2002, Lean Six Sigma: Combining Six Sigma Quality with Lean Speed, McGraw Hill Publications Limited, New York.

[2] Harry M and Schroeder R; 2000, Six-Sigma: The Breakthrough Management Strategy Revolutionizing the World's Top Corporations, Century Doubleday Publications, New York.

[3] Hensley R L \& Dobie K; 2005, Assessing Readiness for Six Sigma in a Service Setting, Managing Service Quality, Vol. 15, No. 1, Pp. 82-101.

[4] Mahanti R \& Antony J; 2005, Confluence of Six Sigma, Simulation and Software Development, Managerial Auditing Journal, Vol. 20, No. 7, Pp.739-762.

[5] Pande P S, Neumen R P \& Cavanagh R R; 2003, the Six Sigma Way, Tata McGraw Hill Publication, New Tork, Page no. XI.

[6] Park S H; 2003, Six Sigma for Quality and Productivity Improvement, Productivity Series 32, Asian Productivity Organization.

[7] Pyzedek Thomas; 2003, the Six Sigma Handbook, McGraw Hill Publications Ltd., New York.

[8] Seung J Rhee and Kosuke Ishii; 2003, Using cost Based FMEA to Enhance Reliability \& Serviceability, Journal of Advanced Engineering Informatics, Vol.17, Pp. 179-188. 
Annexure - I Table no.: 6 FMEA Chart

\begin{tabular}{|c|c|c|c|c|c|c|c|c|c|}
\hline $\begin{array}{l}\text { Process } \\
\text { function } \\
\text { require } \\
\text { ment }\end{array}$ & $\begin{array}{c}\text { Potential } \\
\text { failure mode }\end{array}$ & $\begin{array}{l}\text { Potential } \\
\text { effect of } \\
\text { failure }\end{array}$ & ¿্ঠ & $\begin{array}{l}\text { Potential causes } \\
\text { of failure }\end{array}$ & 苞 & 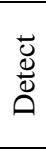 & $\frac{Z}{\alpha}$ & Recommended Action & $\begin{array}{l}\text { Action } \\
\text { Result }\end{array}$ \\
\hline \multirow{4}{*}{ 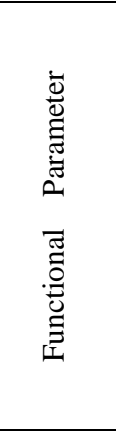 } & $\begin{array}{l}\text { Solder material } \\
\text { on neck }\end{array}$ & $\begin{array}{l}\text { Rejection of } \\
\text { element }\end{array}$ & 7 & $\begin{array}{l}\text { No use of full } \\
\text { proof fixture }\end{array}$ & 5 & 3 & $\underline{105}$ & $\begin{array}{l}\text { Use of fixture \& use of } \\
2 \text { solder bit per day }\end{array}$ & Defect is reduced \\
\hline & $\begin{array}{l}\text { Inadequate } \\
\text { soldering }\end{array}$ & $\begin{array}{l}\text { Rejection } \\
\text { of element }\end{array}$ & 7 & $\begin{array}{l}\text { 1.Quantity of } \\
\text { solder material }\end{array}$ & 5 & 3 & $\underline{105}$ & Use of soldering fixture & Defect is reduced \\
\hline & $\begin{array}{c}\text { Broken } \\
\text { Indicator Wire }\end{array}$ & $\begin{array}{l}\text { Rejection of } \\
\text { fuse }\end{array}$ & 6 & $\begin{array}{l}\text { 1.Wire Strength } \\
\text { 2.Operator skill }\end{array}$ & 4 & 2 & 48 & $\begin{array}{c}\text { Changes in assembly } \\
\text { fixture }\end{array}$ & Defect is reduced \\
\hline & $\begin{array}{l}\text { Not Within } \\
\text { Band }\end{array}$ & $\begin{array}{l}\text { Rejection of } \\
\text { fuse }\end{array}$ & 7 & $\begin{array}{l}\text { 1.Damaged } \\
\text { element } \\
\text { 2.Improper spot } \\
\text { welding } \\
\end{array}$ & 6 & 3 & $\underline{126}$ & $\begin{array}{l}\text { 1.Use of bins to keep } \\
\text { the material } \\
\text { 2.Stopper combination } \\
\text { for spot welding }\end{array}$ & Defect is reduced \\
\hline \multirow{4}{*}{ 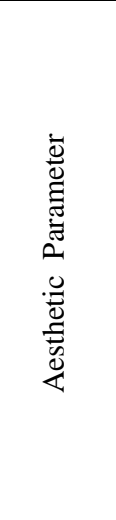 } & $\begin{array}{l}\text { Fuse body chip } \\
\text { off }\end{array}$ & $\begin{array}{l}\text { Rejection of } \\
\text { fuse }\end{array}$ & 4 & $\begin{array}{l}\text { 1.Transportation } \\
\text { 2.Screw fitting } \\
\text { process }\end{array}$ & 3 & 2 & 24 & $\begin{array}{l}\text { 1.Initital inspection } \\
\text { 2.use of bins to avoid } \\
\text { breakage }\end{array}$ & $\begin{array}{l}\text { Chip off defect } \\
\text { identified at } \\
\text { initial stage } \\
\end{array}$ \\
\hline & Printing Defect & $\begin{array}{l}\text { Rework } \\
\text { problem }\end{array}$ & 4 & $\begin{array}{l}\text { Poor maintenance } \\
\text { of printing } \\
\text { machine }\end{array}$ & 4 & 2 & 32 & $\begin{array}{l}\text { 1.Initial inspection } \\
\text { 2.Use of bins to keep } \\
\text { fuse body }\end{array}$ & $\begin{array}{l}\text { Printing defect is } \\
\text { identified at } \\
\text { initial stages, } \\
\text { Rework is } \\
\text { reduced }\end{array}$ \\
\hline & Damaged plug & $\begin{array}{l}\text { Rework } \\
\text { problem }\end{array}$ & 2 & $\begin{array}{l}\text { No piercing, } \\
\text { Size of plug }\end{array}$ & 2 & 2 & 8 & Plug should be checked & Defect is reduced \\
\hline & $\begin{array}{l}\text { Damaged end } \\
\text { plate }\end{array}$ & $\begin{array}{l}\text { Rework } \\
\text { problem }\end{array}$ & 3 & $\begin{array}{l}\text { Fixture at screw } \\
\text { fitting, } \\
\text { Dimensions of } \\
\text { end plate }\end{array}$ & 2 & 2 & 12 & $\begin{array}{l}\text { Check end plate during } \\
\text { screw fitting, }\end{array}$ & $\begin{array}{l}\text { Rework is } \\
\text { reduced }\end{array}$ \\
\hline
\end{tabular}

Annexure 2: Table 8: Statistical Analysis from Pareto Diagrams

\begin{tabular}{|c|c|c|c|c|c|c|}
\hline Type of Defect & \% Defect (May) & Status & $\%$ Defect (June) & Status & $\%$ Defect (July) & Status \\
\hline Not within band & 23.11 & Major & 17.65 & Reduced & 37.55 & Major \\
\hline Solder on neck & 18.51 & Major & 15.87 & Reduced & 16.52 & Minor \\
\hline Inadequate soldering & 18 & Major & 14.39 & Reduced & 12.14 & Reduced \\
\hline Other rejections & 15.5 & Major & 9.23 & Reduced & 21.78 & Major \\
\hline Indicator wire broken & 11.13 & Major & 8.73 & Reduced & 5.63 & Minor \\
\hline Fuse Body chip off & 5.88 & Minor & 10.52 & Major & 6.51 & Minor \\
\hline
\end{tabular}

